\title{
Bacterivory by heterotrophic nanoflagellates in marine sediments measured by uptake of fluorescently labeled bacteria
}

\author{
B. J. M. Hondeveld, R. P. M. Bak, F. C. van Duyl \\ Netherlands Institute for Sea Research (NIOZ), PO Box 59, 1790 AB Den Burg, Texel, The Netherlands
}

\begin{abstract}
In situ grazing of heterotrophic nanoflagellates on bacteria in marine sediments was investigated. We adapted a method to study the intake of food particles, i.e. fluorescently labeled bacteria (FLB), to use with flagellates in sediments. Effects of different techniques to disperse the added FLB in sediments were studied. The variables measured were flagellate density, grazing rate, percentage of flagellates with flagellum and percentage of flagellates containing FLB. In order to relate grazing rates to flagellate biovolume, flagellate cell dimensions were measured. To correct for cell shrinkage due to fixation we measured shrinkage in 4 cultured benthic flagellate species. In sandy sediments nanoflagellate grazing rates varied between 0 and 104 bacteria flagellate ${ }^{-1} h^{-1}$ and increased with increasing flagellate biovolume. Cell biovolume shrinkage ranged widely depending on species, fixation and staining (range 21 to $57 \%$ ). No differences were found between the effects of the various mixing methods on any of the measured parameters. Percentage of total flagellates in the community ingesting FLB varied between 5 and 27. The occurrence in our sediment samples of flagellates without ingested FLB is discussed.
\end{abstract}

\section{INTRODUCTION}

The importance of the microbial food web in planktonic ecosystems, in terms of energy transport and mineralization, is now generally recognized. Heterotrophic nanoflagellates are the major consumers of bacteria in these systems (Fenchel 1982, Azam et al. 1983, Linley et al. 1983, Davis \& Sieburth 1984, Wikner \& Hagström 1988, Sherr et al. 1989). In their turn nanoflagellates are preyed upon by zooplankton, thus providing an indirect route of transfer of primary production to macro-zooplankton.

In contrast, studies on the benthic microbial food web have been few and there is very little known about the relationships or even densities of the microbial components. Consequently, there is hardly any information on basic processes such as the fate of benthic bacterial production in marine sediments. A possible hypothesis is that the impact of meio/ macrofauna is a deciding factor. Grazing of these organisms would stimulate bacterial growth (e.g. Tietjen 1980). Kemp (1987) studied bacterivory by a sediment-ingesting polychaete and concluded that in all likelihood macrofauna seldom ingests more than a few percent of benthic bacterial production. Hansen et al. (1987) suggest deposit-feeding macrobenthos to play a major role in the functioning of the microbial community in coral reef sediments, but they found no correlation between bacterial numbers and growth rates and meiofaunal densities. In situ measurement of meiobenthic grazing indicated a significant stimulatory effect on the microbial community (Montagna 1984). Alongi (1988a, b), in contrast, found no correlation between meiofaunal densities and benthic bacterial biomass and growth rates in tropical sediments. It seems that the magnitude of the interference of macro- and meiofauna with bacterial production leaves ample space to cast phagotrophic protists for a major role in the benthic microbial food web.

Some data show that benthic protozoa graze on bacteria. Fenchel (1975) calculated that ciliates grazed ca $8 \%$ of the standing stock of benthic bacteria in an Arctic tundra pond per day. Ciliate bacterivory measured in saltmarsh, saline pond and mangrove 
sediments accounts for less than $4 \%$ of bacterial abundance per day or of minimum hourly bacterial production (Kemp 1988).

The reasons for the general lack of benthic studies are the specific characteristics of the sediment, presenting difficulties unknown in studies of the pelagic system. These problems include the difficulty of quantitative extraction of the organisms from their habitat and the inhomogeneity of marine bottoms. The last point forces the benthologist to the tedious study of series of replicas.

Nanoflagellates live in the interstitial pores, an often mechanically unstable habitat in shallow seas (see review by Patterson et al. 1989). Free oxygen occurs only in the upper reaches of the sediment. Besides this vertical zonation in sediments, horizontal patterns occur and small aggregates of organic matter may create microhabitats as small as $100 \mu \mathrm{m}$ in diameter (Fenchel 1987, Patterson et al. 1989)

Alongi (1988a, b, 1990) found densities of benthic flagellates in the Great Barrier Reef to be low and concluded that bacterial growth and biomass in tropical marine sediments are primarily regulated by physico-chemical factors instead of being controlled by protozoan grazing. However, the technique used probably results in underestimates of cells smaller than 5 to $10 \mu \mathrm{m}$, which is reported to be the dominant size class in temperate sediments (Bak \& Nieuwland 1989). Using epifluorescence microscopy high and fluctuating densities of nanoflagellates, ranging from winter densities of 50 to $100 \times 10^{3} \mathrm{~cm}^{-3}$ to higher summer levels of 150 to $300 \times 10^{3} \mathrm{~cm}^{-3}$, have been measured in marine intertidal sediments (Bak \& Nieuwland 1989). There was a suggestion of a positive correlation between the productivity of benthic bacteria and flagellate densities (Bak \& Nieuwland 1989, Duyl \& Kop 1990). Additional evidence for a significant role of heterotrophic nanoflagellates is from Larsen \& Patterson (1990). They note that in some tropical marine sediments flagellates are the most widespread and common of all consumers, usually outnumbering other phagotrophic protists as well as metazoa. In view of such data it seems likely that a microbial food web, in which nanoflagellates play an important role, is also present in sediments.

Current methods to estimate the grazing potential of nanoflagellates in the pelagic include the correlation of the abundance of predators and prey (Sherr \& Sherr 1984), the difference between potential and observed bacterial growth rates (Davis \& Sieburth 1984), or the comparison of prey densities with and without predators (Fuhrman \& McManus 1984, Wright \& Coffin 1984). Grazing rates obtained by any of these indirect methods are likely to be burdened by several potentially faulty assumptions. New methods in which phagotrophy is measured by particle uptake were an improvement. Short-term protozoan grazing can be measured through the ingestion rate of monodispersed, fluorescent latex microspheres (Børsheim 1984) or more recently monodispersed, fluorescently labeled bacteria (Sherr et al. 1987). Grazing rates of heterotrophic nanoflagellates measured with microspheres were relatively low and it appeared that at least part of the nanoflagellates selected against these microspheres (McManus \& Fuhrman 1986, Pace \& Bailiff 1987, Sherr et al. 1987, Bloem et al. 1988, Nygaard et al. 1988) or that nanoflagellates egested microspheres after fixation (Cynar \& Sieburth 1986, Sieracki et al. 1987). Uptake of fluorescently labeled bacteria (FLB) seems the best method for estimating instantaneous rates of in situ protozoan grazing so far. We adjusted the FLB method to estimate flagellate grazing directly in sediments.

\section{MATERIALS AND METHODS}

We conducted 2 sets of grazing experiments: the first, April 1990, to establish the method and obtain nanoflagellate grazing rates, and the second, January 1991 , to test the effects of variations in mixing technique.

Experimental communities. In our experiments we used natural 'wild' heterotrophic nanoflagellate communities occurring in natural marine sandy sediments. Sediment samples were collected in pools on the intertidal flats of the western Wadden Sea near the island of Texel. Samples were cored manually with polymethylmetacrylate tubes (26 mm inner diameter) and transported to the Iab. The top layer of the sediment core ( 0 to $3 \mathrm{~mm}$ ) was cut of and used in our experiments $\left(1.6 \mathrm{~cm}^{3}\right)$.

Bacterial and flagellate densities. To calculate the amount of FLB to be added in grazing experiments it is necessary to know the abundance of naturally occurring bacteria. Sediment bacteria were counted in 5 replicate cores after staining with acridine orange according to the method described by Duyl \& Kop (1990). We used a Zeiss Axiophot epifluorescence microscope with a $\mathrm{HBO}$ $50 \mathrm{~W}$ bulb and filterset BP 450/490, FT 510, LP 520. At least 200 bacteria were enumerated in 10 to 20 fields. The sizes of at least 100 bacteria were ranked in 9 size classes in order to estimate biovolumes.

Grazing pressure by a flagellate population is a function of their density and their ingestion rate. We counted flagellates in 5 replicate cores using epifluorescence microscopy after staining with proflavine (Bak et al. 1991). Only non-pigmented flagellates were enumerated. Flagellates were not identified because, with the exception of choanoflagellates and dinoflagellates, it is impossible to identify fixed flagellates (D. Patterson pers. comm.). 
Preparation of fluorescently labeled bacteria (FLB). FLB were prepared from natural bacterioplankton in February 1990 (first series of experiments) and January 1991 (second series of experiments). After filtration of North Sea water through $5.0 \mu \mathrm{m}$ Nuclepore membrane filters, bacteria were grown in batch enriched with $60 \mathrm{mg} \mathrm{l}^{-1}$ Bacto-casitone, $10 \mathrm{mg} \mathrm{l}^{-1}$ yeast extract and $30 \mathrm{mg} \mathrm{l}^{-1} \mathrm{D}(+)$-glucose-monohydrate. After 4 to $5 \mathrm{~d}$ incubation at $15^{\circ} \mathrm{C}$, bacteria were harvested by centrifugation in an MSE high-speed 18 centrifuge with a $43114-106$ rotor $(8 \times 50 \mathrm{ml})$ at $13500 \mathrm{rpm}$ $(22000 \times g)$ for $15 \mathrm{~min}$. Pellets were combined and resuspended in $10 \mathrm{ml} 0.05 \mathrm{M} \mathrm{Na}_{2} \mathrm{HPO}_{4}-0.85 \% \mathrm{NaCl}$ and subsequently $2 \mathrm{mg}$ of 5-(4,6-dichlorotriazin-2-yl) aminofluorescein (DTAF, Sigma Chemical Co., St. Louis, MO, USA) was added to stain the cells. The standard procedure of Sherr et al. (1987) was used. After cooling, portions of $1 \mathrm{ml}$ of stock volume were stored in a freezer at $-20^{\circ} \mathrm{C}$ until use.

The FLB for both series of experiments were measured and classified in 9 size classes using our microscope and filter set BP 450/490, FT 510, LP 520 with a magnification of 1250

Grazing experiments. To estimate flagellate ingestion rates, FLB were added to sediment samples at densities that would give a final FLB concentration of $25 \%$ of total bacterial abundance. Stock FLB was thawed, sonicated with an ultrasonic disintegrator (Soniprep, MSE) at a $30 \mathrm{~W}$ power level for six $1 \mathrm{~s}$ bursts to disperse bacterial clumps, and enumerated. At this time FLB were microscopically examined to avoid use of agglomerated samples. To facilitate the dispersion of FLB through the sediment, $200 \mu \mathrm{l}$ of $0.2 \mu \mathrm{m}$ filtered seawater was added to the samples. After addition of the FLB, $5 \mathrm{~s}$ of low speed vortex-mixing was used to disperse the labeled bacteria. Except for the addition of FLB before the grazing experiments, there was no manipulation of the sediment samples. We assumed (Kemp 1988) that slurrying of the shallow surficial layers of sediment, which are normally subject to resuspension, introduced no measurable artefacts in measurements of flagellate ingestion rates. After mixing, the sample was incubated for $30 \mathrm{~min}$ in the dark at in situ temperature.

The incubation time interval should allow ample time for grazing but is limited by flagellate bacterial digestion (35 to $40 \mathrm{~min}$ at $19^{\circ} \mathrm{C}$; Sherr et al. 1988). After incubation the sediment sample was washed in sterile seawater and $1 \%$ ice-cold glutaraldehyde (total volume of $25 \mathrm{ml}$ ) to extract the flagellates from the sediment. After gentle shaking ( 8 to 10 times) this was allowed to stand for $2 \mathrm{~h}$. A plastic syringe, distal part cut off, was used to take $2.5 \mathrm{ml}$ of the supernatant. The flagellates in the supernatant were stained with primulin and collected on $1.0 \mu \mathrm{m}$ pore size Nuclepore filters stained with Sudan Black. These filters were mounted on slides with immersion oil, and stored at $-20^{\circ} \mathrm{C}$ until analysis.

Slides were scanned with the epifluorescence microscope $(1250 \times)$ using filter set BP365, FT395, LP397 to locate nanoflagellates. Length and width of 240 cells were measured in order to calculate biovolumes, assuming cells to have geometrical shapes (spheres, rotation ellipsoids). Subsequently these flagellates were examined using filter set BP 450/490, FT 510, LP 520 to score numbers of flagellates containing FLB per 240 flagellates examined and to enumerate ingested FLB per flagellate. To decide whether FLB were actually inside flagellates we used the criterion of their being in the same focal plane as the flagellates.

In pelagic experiments grazing rates are calculated from the change in average number of FLB cell-1 with time, using simple regression analysis (Nygaard et al. 1988, Bloem et al. 1989, Sherr et al. 1989). In these studies the calculation of the average number of FLB cell ${ }^{-1}$ is not explicitly mentioned. Bloem (pers. comm.) calculated FLB ingestion rates as total number of FLB ingested divided by total number of flagellates examined. In these pelagic grazing experiments not all flagellates ingested FLB: flagellates with FLB vary from 2 to $94 \%$ depending on fixative used and flagellate species (Sieracki et al. 1987 , Nygaard et al. 1988, Sherr et al. 1989). Obviously average number of FLB cell ${ }^{-1}$ depends highly on the percentage of flagellates ingesting FLB. McManus \& Okubo (1991) evaluated the use of surrogate food particles to measure protistan ingestion and state that it is not correct to consider all flagellates not containing FLB to be nongrazers.

Therefore we decided to calculate average FLB ingestion rates by 2 methods in parallel: (1) a calculation method based on total number of FLB ingested divided by total number of flagellates examined, possibly giving minimum values, and (2) a calculation method based on total number of FLB ingested divided by total number of flagellates containing FLB, possibly representing maximum estimates.

In our second set of experiments, we performed 6 experiments (in triplicate) to investigate mixing effects. Three intensities of vortex-mixing were used to disperse the added FLB: 5, 15 and $30 \mathrm{~s}$ at low speed. As an alternative we stirred with 2 bars of glass in semicircles through the slurry: 5,15 or 30 times (the Bakers transformation; Ottino 1989). We scored numbers of flagellates containing FLB per 100 flagellates examined and enumerated ingested FLB per flagellate to measure grazing rates. Total numbers of flagellates and flagellates with flagellum were scored to estimate the influence of mixing methodology. The loss of a flagellum was used as a grade for the harmful effects of mixing. In 
these experiments only 100 flagellates were examined per slide and we did not measure flagellate cell dimensions.

Fixation experiments to measure flagellate biovolume shrinkage. To relate flagellate grazing to flagellate biovolume we measured flagellate cell dimensions. Because flagellates shrink after fixation (Bloem et al. 1988, D. Patterson pers. comm.) cell volume shrinkage of 4 cultured benthic flagellate species was measured in order to obtain a correction factor for biovolume measurements of flagellates in field samples.

Cell volumes of live flagellate cells were compared to cell volumes of fixed and stained flagellate cells. The effect of 2 different stains on the shrinkage of cell volumes of flagellates was studied. We used 4 species of benthic flagellates isolated from marine sediments: Bodo designis Skuja, B. saliens Larsen \& Patterson, a Rhyncomonas sp. and 1 unidentified species. $\mathrm{A} \mathrm{MgCl}_{2}$ solution (50 g per $100 \mathrm{ml} 0.2 \mu \mathrm{m}$ filtered seawater) was used to slow down the flagellates, in order to measure live cells by phase contrast, with magnification of 600 . We assumed that there was no effect of this $\mathrm{MgCl}_{2}$ solution on flagellate cell dimensions. After fixation with ice-cold glutaraldehyde (final concentration $1 \%$ ) samples of 3 species were stained with both proflavine and primulin. B. saliens was only stained with proflavine. Flagellates were collected on $0.2 \mu \mathrm{m}$ pore size Nuclepore filters stained with Sudan Black and mounted on slides with immersion oil. Subsequently they were measured using epifluorescence microscopy. Dimensions of 50 flagellates from each flagellate species at each treatment were measured. All measurements were done within $4 \mathrm{~h}$ after fixation. Shrinkage due to fixation/staining was expressed as percentage loss of biovolume with respect to the biovolume of live cells

\section{RESULTS}

\section{Comparison of sizes of FLB with in situ bacteria}

The biovolume frequency distributions of in situ bacteria and FLB used in the first set of grazing experiments are compared in Fig. 1a, b. There was an appreciable difference in size range of the FLB compared to the in situ bacteria. Of the FLB $85.7 \%$ were larger than $0.226 \mu \mathrm{m}^{3}$ while this was only $22.1 \%$ for the in situ bacteria. The average biovolume was $0.63 \mu \mathrm{m}^{3} \mathrm{FLB}^{-1}$ vs $0.20 \mu^{3}$ (in situ bacterium) $)^{-1}$.

The FLB used in the second set of experiments were also larger than the in situ bacteria but the difference

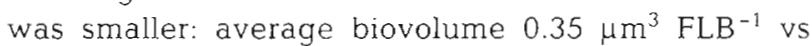
$0.24 \mu^{3}$ (in situ bacterium) $)^{-1}$. The biovolume frequency distributions of in situ bacteria and FLB are compared in Fig. 1c, d.

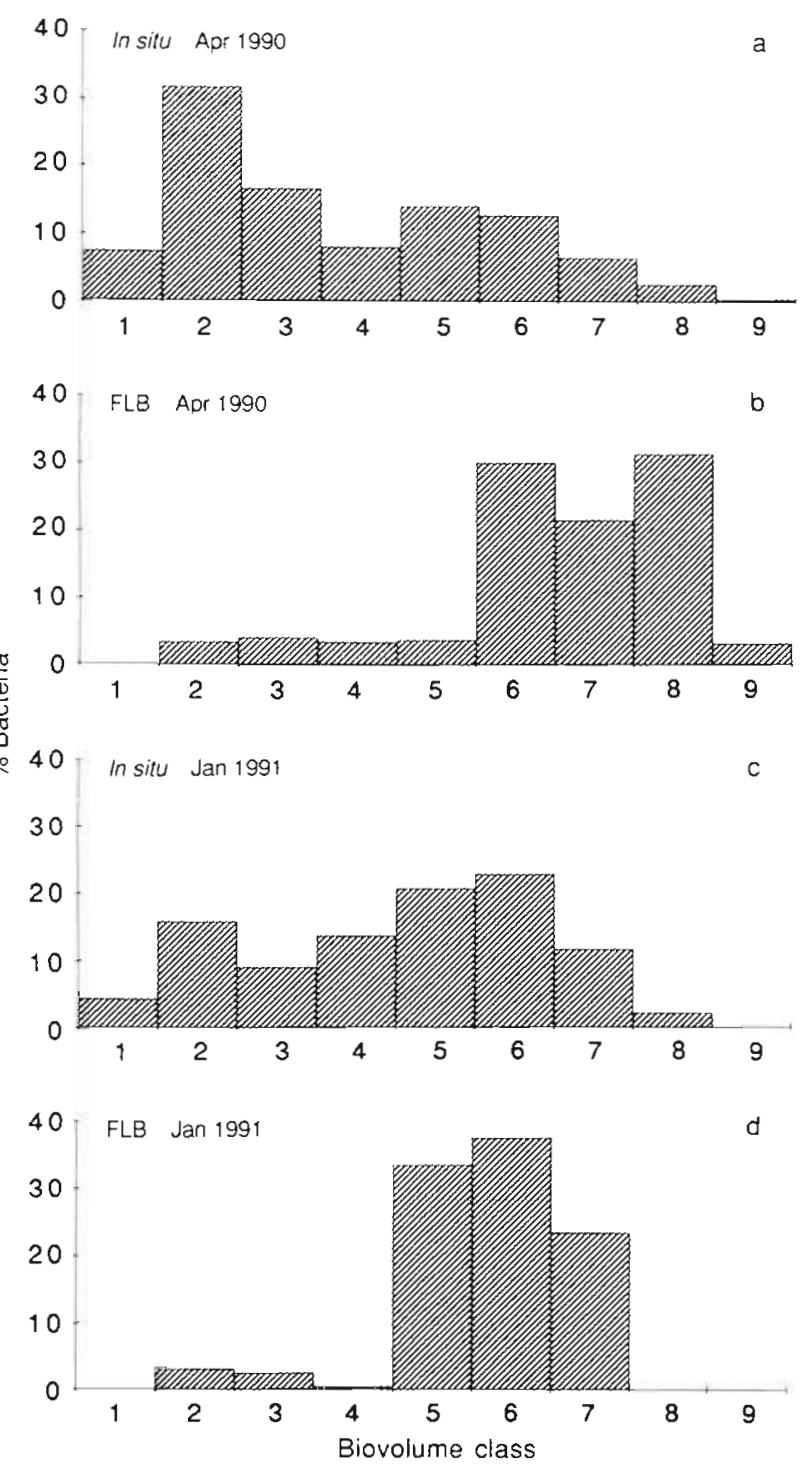

Fig. 1. Biovolume frequency distributions of $(a \& c)$ in situ bacteria and (b \& d) fluorescently labeled bacteria, FLB, from April 1990 and January 1991 Biovolume classes: $1=0.004 \mathrm{~mm}^{3}$; $2=0.034 ; 3=0.101 ; 4=0.166 ; 5=0.226 ; 6=0.260 ; 7=0.584 ;$ $8=1.005 ;$ and $9=2.011$

\section{Fixation experiments to measure flagellate biovolume shrinkage}

Comparison of biovolume measurements of the very slow-moving unidentified species without addition of $\mathrm{MgCl}_{2}$ (data not presented) with data obtained after addition of $\mathrm{MgCl}_{2}$ justified the assumption that $\mathrm{MgCl}_{2}$ has no effect on cell dimensions.

Cell volume shrinkage of 4 benthic flagellate species ranged from 21 to $57 \%$ with a mean of $36 \%$ for flagellates stained with proflavine and $41 \%$ for flagellates stained with primulin (Table 1). There was a significant difference in shrinkage between specimens stained 
Table 1. Biovolume measurements $\left(\mu \mathrm{m}^{3}\right)$ of 4 benthic flagellate species from marine sediments live and fixed (1\% glutaraldehyde) and stained with either proflavine or primulin. Mean values $\pm \mathrm{SE} .(-)=$ not measured

\begin{tabular}{|lccccc|}
\hline Species & $\begin{array}{c}\text { Biovolume } \\
\text { Live }\end{array}$ & $\begin{array}{c}\text { Biovolume } \\
\text { Fixed, proflavine }\end{array}$ & $\begin{array}{c}\% \\
\text { Shrinkage }\end{array}$ & $\begin{array}{c}\text { Biovolume } \\
\text { Fixed, primulin }\end{array}$ & $\begin{array}{c}\text { Shrinkage } \\
\text { Bodo saliens }\end{array}$ \\
Bodo designis & $23.3 \pm 11.4$ & $18.5 \pm 20.8$ & 20.6 & - & 22.8 \\
Rhyncomonas sp. & $17.1 \pm 7.3$ & $11.0 \pm 4.3$ & 35.7 & $13.2 \pm 4.3$ & $6.4 \pm 2.7$ \\
Unknown species & $11.4 \pm 5.7$ & $6.2 \pm 2.2$ & 46.0 & $4.6 \pm 1.8$ & 57.0 \\
\hline
\end{tabular}

with either proflavine or primulin for Bodo designis and for the small unidentified species (ANOVA, $p=0.013$ and $p=0.001$ respectively). $B$. designis shrank less when stained with primulin than with proflavine. For the small unidentified species it was the other way around. In Rhyncomonas sp. there was no significant difference between the 2 fluorochromes (ANOVA, $p=0.67$ ).

\section{Grazing experiments}

The first set of grazing experiments was performed in April 1990. During these 4 experiments bacterial abundance in consecutive samples increased (Table 2). Flagellate abundance ranged from $95.9 \times 10^{3}$ to $194.1 \times 10^{3}$ flagellates $\mathrm{cm}^{-3}$.

In the grazing experiments numbers of flagellates ingesting FLB were rather low on 10,13 and 18 April compared to the high number of flagellates with FLB on 2 April (Table 2). In the latter, $27 \%$ of all flagellates examined ingested FLB vs 5.8 to $8.3 \%$ in the other 3 experiments.

The number of FLB ingested varied between 0 and 12 FLB flagellate $^{-1}(0.5 \mathrm{~h})^{-1}$. We assumed that for each FLB ingested, 3 in situ bacteria were eaten because FLB constituted only $25 \%$ of the total bacterial abundance and the likelihood of a flagellate encountering a labeled bacterium and an in situ bacterium was 0.25 and 0.75 respectively. Grazing rates were then calculated to be 0 to 96 bacteria flagellate ${ }^{-1} \mathrm{~h}^{-1}$. Mean values, calculated by the first method and based on total number of flagellates examined, ranged from 2.5 to 11.8 bacteria flagellate ${ }^{-1}$ $\mathrm{h}^{-1}$ (Table 2). Using the other method of calculation based on total number of flagellates containing FLB, the mean values ranged from 35.6 to 45.6 bacteria flagellate $^{-1} \mathrm{~h}^{-1}$ (Table 2). Mean grazing rates did not vary significantly among dates in April (ANOVA, $p=0.183$ ).

All flagellates examined for FLB were also measured in order to estimate their biovolumes. Biovolume measurements were corrected for shrinkage using the average shrinkage percentage of 41 for flagellates stained with primulin. The relation between grazing rate, in terms of total number of bacterial cells ingested per hour and flagellate biovolume is shown in Fig. 2a. Grazing rates varied widely for flagellates of a given size with a significant increase in grazing with increasing flagellate biovolume ( $\mathrm{n}=188, \mathrm{r}=0.447, \mathrm{p}<0.01)$. Grazing rates expressed as \% flagellate biovolume ingested $\mathrm{h}^{-1}$ are shown in Fig. 2b. Grazing rates declined significantly with increasing flagellate biovolume ( $\mathrm{n}=188, \mathrm{r}=0.574, \mathrm{p}<0.01)$. The smallest flagellates can ingest 90 to $100 \%$ of their cell volume $\mathrm{h}^{-1}$, and the largest only 5 to $10 \%$

The flagellates measured were classified in the biovolume groups $0-5,5-15,15-25,25-40,40-70$ and $70-120 \mu \mathrm{m}^{3}$. Within a biovolume group we can distinguish flagellates containing FLB and flagellates without FLB. It appeared that relatively large flagellates $\left(>15 \mathrm{\mu m}^{3}\right.$ ) more often ingested FLB than smaller flagellates $\left(<15 \mu \mathrm{m}^{3}\right.$, Fig. 3).

Table 2. Comparison of bacterial abundance, flagellate abundance, \% flagellates containing FLB and grazing rates on 4 dates in April 1990. Mean values $\pm \mathrm{SE}, \mathrm{n}$ in parentheses. Calculation of mean grazing rates: Method 1: total no. of bacteria consumed/ total no. of flagellates examined; Method 2: total no. of bacteria consumed/total no. of flagellates containing FLB

\begin{tabular}{|c|c|c|c|c|c|}
\hline \multirow{2}{*}{$\begin{array}{l}\text { Sample } \\
\text { date }\end{array}$} & \multirow{2}{*}{$\begin{array}{c}\text { Bacterial } \\
\text { abundance } \\
\left(\times 10^{9} \text { cells } \mathrm{cm}^{-3}\right)\end{array}$} & \multirow{2}{*}{$\begin{array}{l}\text { Flagellate } \\
\text { abundance } \\
\left(\times 10^{3} \text { cells } \mathrm{cm}^{-3}\right)\end{array}$} & \multirow{2}{*}{$\begin{array}{c}\% \text { Flagellates } \\
\text { containing } \\
\text { FLB }\end{array}$} & \multicolumn{2}{|c|}{$\begin{array}{c}\text { Mean grazing rate } \\
\text { (bacteria flagellate }{ }^{-1} \mathrm{~h}^{-1} \text { ) }\end{array}$} \\
\hline & & & & Method 1 & Method 2 \\
\hline 2 Apr 1990 & $1.88 \pm 0.28$ & $95.9 \pm 7.8$ & 27.0 & $11.8 \pm 21.0 \quad(504)$ & $43.6 \pm 15.1$ \\
\hline 10 Apr 1990 & $1.91 \pm 0.13$ & $174.5 \pm 7.9$ & 8.3 & $3.8 \pm 13.4 \quad(240)$ & $45.6 \pm 15.4 \quad(20)$ \\
\hline 13 Apr 1990 & $2.23 \pm 0.14$ & $169.2 \pm 16.7$ & 7.5 & $2.7 \pm 10.5(240)$ & $35.6 \pm 17.4 \quad(18)$ \\
\hline 18 Apr 1990 & $2.21 \pm 0.13$ & $194.1 \pm 22.2$ & 5.8 & $2.5 \pm 10.5(240)$ & $42.9 \pm 12.4 \quad(14)$ \\
\hline
\end{tabular}



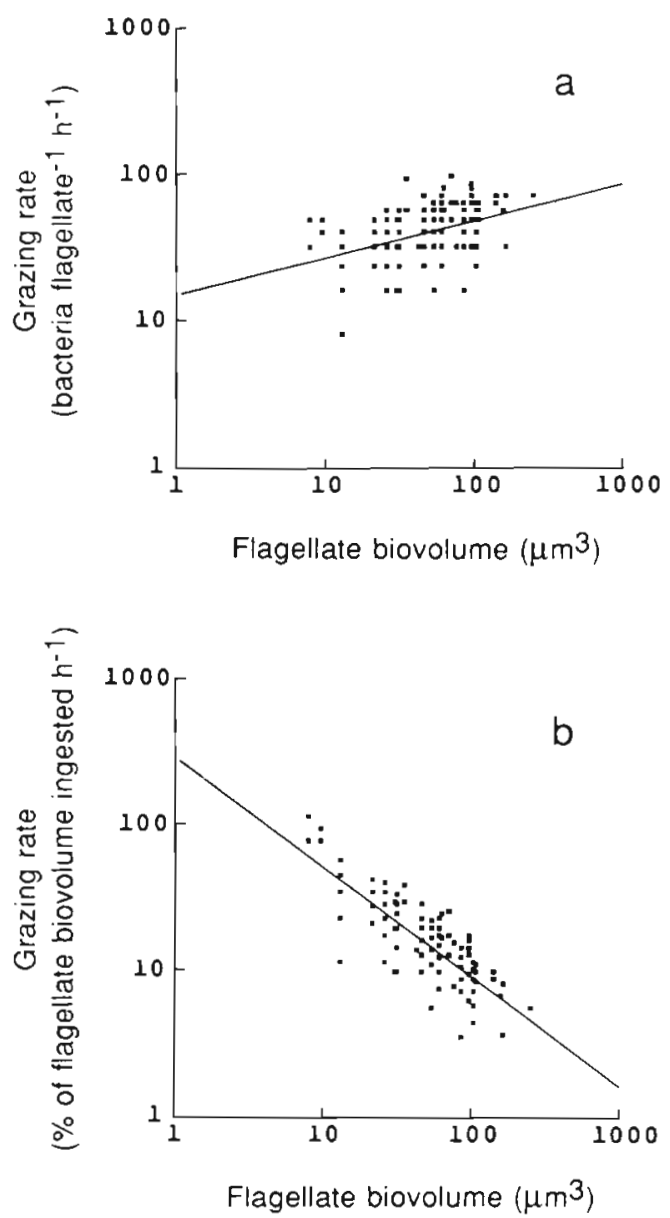

Fig. 2. (a) Grazing rate expressed as bacteria flagellate ${ }^{-1} \mathrm{~h}^{-1}$ plotted against flagellate biovolume. Regression: $y=0.196 x$ $+32.190, p<0.01$ (b) Grazing rate expressed as \% flagellate biovolume ingested $\mathrm{h}^{-1}$ plotted against flagellate biovolume. Regression: $y=-0.238 x+33.065, p<0.01$

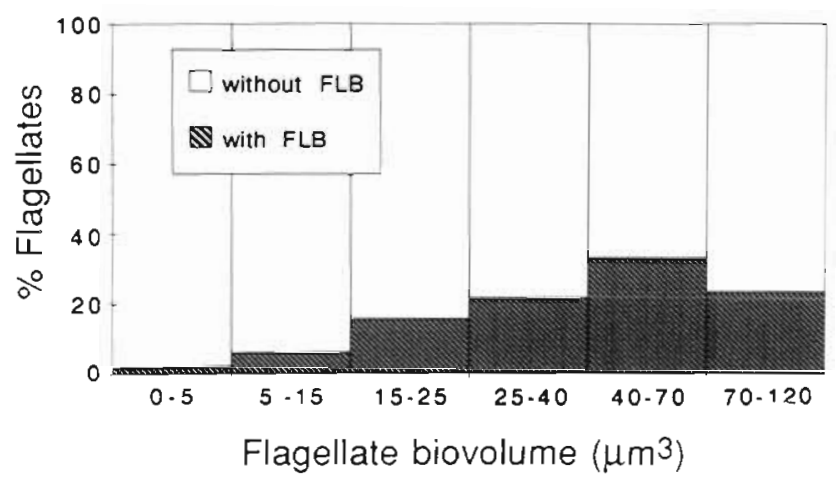

Fig. 3. Biovolume frequency distribution of all flagellates $(n=188)$ with and without FLB measured in April 1990

The second set of grazing experiments was performed in January 1991. Table 3 shows how the different treatments influenced flagellate numbers, percentage of flagellates containing FLB, grazing rates and percentage of flagellates with flagellum. For all these parameters no significant differences were found between the different types and duration of mixing (Kruskal \& Wallis, all $p>0.1$; since sample sizes were small and the Kruskal \& Wallis-statistic is only asymptotically chi-squared distributed, the p-values were calculated by crude Monte Carlo sampling with the aid of the computer program Statxact).

The percentages of flagellates ingesting FLB varied between 12.7 and $18.3 \%$. This was, on average, higher than in the first set of grazing experiments (Table 3 ).

Individual grazing rates ranged between 0 and 104 bacteria flagellate ${ }^{-1} \mathrm{~h}^{-1}$, which was in the same range as in the first set of experiments.

\section{DISCUSSION}

The function of nanoflagellates in marine sediments is hardly studied. So far information on the importance of the benthic microbial loop and the role of nanoflagellates was based only on extrapolation of data on bacterial production, bacterial numbers and flagellate numbers (Alongi 1988a, b, Bak \& Nieuwland 1989, 1993, Duyl \& Kop 1990, Duyl et al. 1992).

The measured grazing rates range from 0 to 104 bacteria flagellate ${ }^{-1} \mathrm{~h}^{-1}$. Values resulting from studies on planktonic nanoflagellates are in the same range (Fenchel 1982, Davis \& Sieburth 1984, Cynar \& Sieburth 1986, Sherr et al. 1986, Wikner et al. 1986).

Only $20 \%$ of the increase in grazing rate with flagellate biovolume, in total number of bacteria ingested flagellate ${ }^{-1} \mathrm{~h}^{-1}$ (Fig. 2a), can be explained by the increase in flagellate biovolume. The biovolume measurements are corrected for shrinkage using the average of $41 \%$ for fixation and staining with primulin, which is comparable to values reported in the literature (Bloem et al. 1988, Choi \& Stoecker 1989). Peters (1983) suggests that grazing rate is influenced by more variables than just size, viz. by temperature, growth and reproduction. We worked at 1 temperature so this factor had the same impact on all flagellates. Changes in metabolic activity during the generation time could be a factor of importance in determining grazing rates. Non-continuous feeding has already been observed during cell division (Cynar \& Sieburth 1986).

Grazing rates ( $\%$ flagellate biovolume ingested $h^{-1}$ ) declined substantially with increasing flagellate biovolume (Fig. 2b). Decrease in grazing rate is expected due to decreasing biomass-specific metabolic rate with increasing biomass. Fenchel (1980) suggests that metabolic costs are responsible for such decrease in grazing rate with increasing biovolume. This would imply that all flagellates in the 5 to $120 \mu \mathrm{m}^{3}$ biovolume range consume the same relative amount of bacteria. 
Table 3. Comparison of the effect of 6 different mixing methods/duration on flagellate densities, percentages of flagellates containing FLB, grazing rates and percentages of flagellates with flagellum. V: vortex, 5, 15 and $30 \mathrm{~s}$; S: stir, 5, 15 and 30 times. Mean values $\pm S E, n$ in parentheses. Calculation of mean grazing rates: Method 1, total no. of bacteria consumed/total no. of flagellates examined; Method 2, total no. of bacteria consumed/total no. of flagellates containing FLB

\begin{tabular}{|cccccc|}
\hline Method & $\begin{array}{c}\text { Flagellate density } \\
\left(\times 10^{3} \mathrm{~cm}^{-3}\right)\end{array}$ & $\begin{array}{c}\text { \% Flagellates } \\
\text { containing FLB }\end{array}$ & $\begin{array}{c}\text { \% Flagellates } \\
\text { with flagellum }\end{array}$ & $\begin{array}{c}\text { Mean grazing rate } \\
\text { (bacteria flagellate } \mathrm{h}^{-1} \text { ) } \\
\text { Method } 1\end{array}$ \\
\hline V05 & $94.6 \pm 12.3(3)$ & $17.7 \pm 1.5(3)$ & $62.3 \pm 3.5(3)$ & $6.1 \pm 1.5(3)$ & $33.9 \pm 5.8(3)$ \\
V15 & $100.8 \pm 16.9(3)$ & $18.3 \pm 2.1(3)$ & $64.7 \pm 3.5(3)$ & $5.8 \pm 0.1(3)$ & $32.2 \pm 4.2(3)$ \\
V30 & $89.6 \pm 6.0(3)$ & $13.0 \pm 7.0(3)$ & $53.3 \pm 9.3(3)$ & $4.2 \pm 2.8(3)$ & $30.1 \pm 5.5(3)$ \\
S05 & $107.2 \pm 25.2(3)$ & $16.0 \pm 4.4(3)$ & $63.3 \pm 9.0(3)$ & $3.7 \pm 1.2(3)$ & $22.9 \pm 1.7(3)$ \\
S15 & $94.5 \pm 11.2(3)$ & $15.3 \pm 3.8(3)$ & $53.0 \pm 2.6(3)$ & $5.7 \pm 2.3(3)$ & $36.1 \pm 6.7(3)$ \\
S30 & $95.9 \pm 13.2(3)$ & $12.7 \pm 9.1(3)$ & $56.7 \pm 3.2(3)$ & $3.6 \pm 2.6(3)$ & $31.5 \pm 3.0(3)$ \\
\hline
\end{tabular}

In our first set of grazing experiments the percentages of flagellates with FLB were rather low (5 to $8 \%$ ) except on 2 April when $27 \%$ of all flagellates ingested FLB. A possible explanation for these low percentages is inadequate mixing of the slurry. The $5 \mathrm{~s}$ vortex at low speed was possibly not enough to distribute the FLB randomly through the sediment. Some flagellates did not eat FLB simply because they did not encounter any. In the second set of grazing experiments this was investigated using 2 methods and 3 intensities of mixing per method (Table 3 ). The percentages of flagellates with FLB were generally higher than in the first set of grazing experiments and ranged from 13 to $18 \%$. But the 6 different mixing intensities showed no significant differences among the percentages of flagellates with FLB. This rules out non-randomness as the cause and invites other explanations.

There are several possible reasons why flagellates may not contain FLB. First, there may be egestion of food vacuole contents upon fixation. The effect of fixation on retention of food vacuole contents varies with flagellate species and fixative used (Cynar \& Sieburth 1986, Sieracki et al. 1987, Bloem et al. 1989, Sherr et al. 1989). In our experiments we used $1 \%$ ice-cold glutaraldehyde. In the literature contradictory results are reported from experiments using this fixative, so we cannot exclude the possibility that also in our experiments egestion of food vacuole contents occurred. Another possible explanation is the use of other food particles/sources, such as detritus, algae, dissolved organic matter, fungi or fragments of other protists or metazoa, by flagellates without ingested FLB (Patterson et al. 1989). Finally, there may be flagellates that will not eat FLB or eat less FLB than they do in situ bacteria.

The primary assumption of the FLB uptake assay is that flagellates do not ingest added FLB either more or less readily than they do in situ bacteria. Causes of discrimination against FLB can be the size or the strain of bacteria used to prepare FLB. We used natural bac- terioplankton grown in batch. In the first set of grazing experiments our FLB were on average 3 times the size of the in situ bacteria. Fig. 3 shows that flagellates smaller than $15 \mu \mathrm{m}^{3}$ did not ingest FLB as often as the larger ones. These small flagellates were probably not able to swallow the enormous FLB.

Another important difference between FLB and in situ bacteria is that FLB are suspended and most in situ cells are attached (81 to $99 \%$; Sich 1990). From studies in the pelagic to investigate the ability of nanoflagellates to graze attached and free bacteria it appeared that surface-associated species showed preferences for attached and aggregated bacteria. Fluid-phase species efficiently grazed unattached bacteria and showed little or no ability to graze attached or aggregated cells (Caron 1987, Sibbald \& Albright 1988). FLB are suspended, unattached bacteria and it is likely that surface-associated flagellate species will ingest no or fewer FLB than fluid-phase flagellates. The relative numbers of fluid-phase and surface-associated flagellates will depend on the nature of the habitat. Interstitial habitats have a relatively large internal surface area which forms a large niche for surface-associated flagellates in the sediment (Patterson et al. 1989).

Mean grazing rates, calculated as total no. of bacteria consumed divided by total no. of flagellates containing FLB, were 5 to 20 times as high as the mean grazing rates calculated in the usual manner. But the latter will severely underestimate mean grazing rates because it is not correct to consider all flagellates not containing FLB to be non-bacterivorous. Discrimination against FLB because of the reasons mentioned above seems very likely and has indeed been reported (Landry et al. 1987. Sherr et al. 1989, Nygaard \& Hessen 1990). We therefore think it is reasonable to assume that the mean grazing rates calculated by the alternative method $(2$, see Tables $2 \& 3$ ) are closer to reality, although we are aware of the fact that there is a possible overestimation of average flagellate grazing on bacteria. 
In conclusion our study shows that it is possible to use fluorescently labeled bacteria as tracer to measure instantaneous nanoflagellate bacterivory in sandy marine sediments. The percentages of flagellates ingesting FLB are at the low end of the range reported in the literature. Similar low percentages were found in pelagic grazing experiments in field samples, whereas in experiments with laboratory cultures of flagellates higher percentages were found (Nygaard et al. 1988, Sherr et al. 1989). From the difference between attached and suspended bacteria for flagellate bacterivory and the occurrence of many attached bacteria in sediments it is apparent that in future research this phenomenon of selective grazing must be studied more extensively.

Acknowledgements. We are grateful to M. Starink, who introduced us to the fluorescently labeled bacteria method and to G. Nieuwland for laboratory assistance. We thank D. Patterson for helping to identify the Rhyncomonas species and Bodo saliens, L. R. M. Maas for the helpful suggestions concerning mixing processes, and $\mathrm{H}$. J. Witte and J. van der Meer for statistical advice. Comments by Dr Paul F. Kemp improved the manuscript. This is publication no. 48 of the project 'Applied Scientific Research', Netherlands Institute for Sea Research

\section{LITERATURE CITED}

Alongi, D. M. (1988a). Bacterial productivity and microbial biomass in tropical mangrove sediments. Microb. Ecol. 15 $59-79$

Alongi, D. M. (1988b). Microbial-meiofaunal interrelationships in some tropical intertidal sediments. J. mar Res. 46(2): $349-365$

Alongi, D. M. (1990). Abundances of benthic microfauna in relation to outwelling of mangrove detritus in a tropical coastal region. Mar. Ecol. Prog. Ser. 63: 53-63

Azam, F., Fenchel, T., Field, J. G., Gray, J. S., Meyer-Reil, L. A., Thingstad, T. F. (1983). The ecological role of water column microbes in the sea. Mar. Ecol. Prog. Ser. 10: 257-263

Bak, R. P. M., Nieuwland, G. (1989). Seasonal fluctuations in benthic protozoan populations at different depths in marine sediments. Neth. J. Sea Res. 24(1): 37-44

Bak, R. P. M., Nieuwland, G. (1993). Patterns in pelagic and benthic nanoflagellate densities in the coastal upwelling system along the Banc d'Arguin, Mauritania. Hydrobiologia (in press)

Bak, R. P. M., Duyl, F. C. van, Nieuwland, G., Kop, A. J. (1991). Benthic heterotrophic nanoflagellates in North Sea field/mesocosm bottoms and their response to algal sedimentation. Ophelia 33(3): 187-196

Bloem, J., Ellenbroek, F. M., Bär-Gilissen, M. J. B., Cappenberg, T E. (1989). Protozoan grazing and bacterial production in stratified Lake Vechten with fluorescently labeled bacteria and by thymidine incorporation. Appl. environ. Microbiol. 55(7): 1787-1795

Bloem, J., Starink, M., Bär-Gilissen, M. J. B., Cappenberg, T E. (1988). Protozoan grazing, bacterial activity, and mineralization in two-stage continuous cultures. Appl. environ. Microbiol. 54(12): 3113-3121
Børsheim, K. Y (1984). Clearance rates of bacteria-sized particles by freshwater ciliates, measured with monodispersed fluorescent latex beads. Oecologia 64: $286-288$

Caron, D. A. (1987). Grazing of attached bacteria by heterotrophic microflagellates. Microb. Ecol. 13: 203-218

Choi, J. W., Stoecker, D. K. (1989). Effects of fixation on cell volume of marine planktonic protozoa. Appl. environ. Microbiol. 55(7): 1761-1765

Cynar, F. J., Sieburth, J. McN. (1986). Unambiguous detection and improved quantification of phagotrophy in apochlorotic nanoflagellates using fluorescent microspheres and concomitant phase contrast and epifluorescence microscopy. Mar. Ecol. Prog. Ser. 32: 61-70

Davis, P. G., Sieburth, J. McN (1984). Estuarine and oceanic microflagellate predation of actively growing bacteria: estimation by frequency of dividing-divided bacteria. Mar. Ecol. Prog. Ser 19: 237-246

Duyl, F. C. van, Bak, R. P. M., Kop, A. J., Nieuwland, G., Berghuis, E. M., Kok, A. (1992). Mesocosm experiments: mimicking seasonal developments of microbial variables in North Sea sediments. Hydrobiologia 235/236: 267-281

Duyl, F. C. van, Kop, A. J. (1990). Seasonal patterns of bacterial production and biomass in intertidal sediments of the western Dutch Wadden Sea. Mar. Ecol. Prog. Ser. 59: $249-261$

Fenchel, T. (1975). The quantitative importance of the benthic microfauna of an arctic tundra pond. Hydrobiologia 46: $445-464$

Fenchel, T (1980). Suspension feeding in ciliated protozod: functional response and particle size selection. Microb. Ecol. 6: 1-11

Fenchel, T (1982). Ecology of heterotrophic microflagellates IV. Quantitative occurrence and importance as bacterial consumers. Mar. Ecol. Prog. Ser. 9: 35-42

Fenchel, T (1987). Ecology of Protozoa. Brock/Springer, Madison

Fuhrman, J. A., McManus, G. B. (1984). Do bacteria-sized marine eukaryotes consume significant bacterial production? Science 224: $1257-1260$

Hansen, J. A., Alongi, D. M., Moriarty, D. J. W., Pollard, P. C. (1987). The dynamics of benthic microbial communities at Davies Reef, central Great Barrier Reef. Coral Reefs 6: $63-70$

Kemp, P. F. (1987). Potential impact on bacteria of grazing by a macrofaunal deposit-feeder, and the fate of bacterial production. Mar. Ecol. Prog. Ser. 36: 151-161

Kemp, P. F. (1988). Bacterivory by benthic ciliates: significance as a carbon source and impact on sediment bacteria Mar. Ecol. Prog. Ser. 49: 163-169

Landry, M. R., Lehner-Fournier, J. M., Fagerness, V. L., Sundstrom, J A., Selph, K. E. (1987). Discriminate feeding of marine protozoa on living versus heat-killed bacteria. Eos 68(50): 1782

Larsen, J., Patterson, D. J. (1990). Some flagellates (Protista) from tropical marine sediments. J nat. Hist. 24: $801-937$

Linley, E. A. S. Newell, R. C., Lucas, M. I. (1983). Quantitative relationships between phytoplankton, bacteria and heterotrophic microflagellates in shelf waters. Mar. Ecol. Prog Ser. 12: $77-89$

McManus, G. B., Fuhrman, J. A. (1986). Bacterivory in seawater studied with the use of inert fluorescent particles Limnol. Oceanogr. 31:420-426

McManus, G. B., Okubo. A. (1991). On the use of surrogate food particles to measure protistan ingestion. Limnol. Oceanogr. 36(3): 613-617 
Montagna, P. A. (1984). In situ measurement of meiobenthic grazing rates on sediment bacteria and edaphic diatoms. Mar. Ecol. Prog. Ser. 18: 119-130

Nygaard, K., Børsheim, K. Y., Thingstad, T F. (1988). Grazing rates on bacteria by marine heterotrophic microflagellates compared to uptake rates of bacterial-sized monodisperse fluorescent latex beads. Mar. Ecol. Prog. Ser. 44: $159-165$

Nygaard, K., Hessen, D. O. (1990). Use of ${ }^{14} \mathrm{C}$-proteinlabelled bacteria for estimating clearance rates by heterotrophic and mixotrophic flagellates. Mar. Ecol. Prog. Ser. 68: 7-14

Ottino, J. M. (ed.) (1989). The kinematics of mixing: stretching, chaos and transport, University Press, Cambridge

Patterson, D. J., Larsen, J., Corliss, J. O. (1989). The ecology of heterotrophic flagellates and ciliates living in marine sediments. In: Patterson, D. J., Corliss, J. O. (eds.) Progress in protistology. Biopress Ltd., Bristol, p. 186-277

Pace, M. L., Bailiff, M. D. (1987). Evaluation of a fluorescent microsphere technique for measuring grazing rates of phagotrophic microorganisms. Mar. Ecol. Prog. Ser. 40: $185-193$

Peters, R. H. (1983). Ingestion. In: Beck, E., Birks, H. J. B., Connor, E. F. (eds.) The ecological implications of body size. University Press, Cambridge, p. 100-117

Sherr, B. F., Sherr, E. B. (1984). Role of heterotrophic protozoa in carbon and energy flow in aquatic ecosystems. In: Klug, M. J., Reddy, C. A. (eds.) Current perspectives in microbial ecology. Am. Soc. Microbiol., Washington, D.C., p. $412-423$

Sherr, B. F., Sherr, E. B., Andrew, T L., Fallon, R. D., Newell, S. Y (1986). Trophic interactions between heterotrophic Protozoa and bacterioplankton in estuarine water analyzed with selective metabolic inhibitors. Mar. Ecol. Prog. Ser. 32: 169-179

This article was submitted to the editor
Sherr, B. F., Sherr, E. B., Fallon, R. D. (1987). Use of monodispersed, fluorescently labeled bacteria to estimate in situ protozoan bacterivory. Appl. environ. Microbiol. 53(5): 958-965

Sherr, B. F., Sherr, E. B., Pedrós-Alió, C. (1989). Simultaneous measurement of bacterioplankton production and protozoan bacterivory in estuarine water Mar. Ecol. Prog. Ser 54: 209-219

Sherr, B. F., Sherr, E. B., Rassoulzadegan, F. (1988). Rates of digestion of bacteria by marine phagotrophic protozoa: temperature dependence. Appl. environ. Microbiol. 543(5): $1091-1095$

Sibbald, M. J., Albright, J. A. (1988). Aggregated and free bacteria as food sources for heterotrophic microflagellates. Appl. environ. Microbiol. 54(2): 613-616

Sich, H. (1990). Benthic ciliates of Gabelsflach (Kiel Bay) and the influence upon them by bacteria. Berichte aus dem Institut für Meereskunde, Kiel

Sieracki, M. E., Haas, L. W., Caron, D. A., Lessard, E. J. (1987). Effect of fixation on particle retention by microflagellates: underestimation of grazing rates. Mar. Ecol. Prog. Ser. 38: 251-258

Tietjen, J. H. (1980). Microbial-meiofaunal interrelationships: a review. Microbiology: $330-340$

Wikner, J., Andersson, A., Normark, S., Hagström, §. (1986). Use of genetically marked minicells as a probe in measurement of predation on bacteria in aquatic environments. Appl. environ. Microbiol. 52(1): 4-8

Wikner, J., Hagström, $\AA$. (1988). Evidence for tightly coupled nanoplanktonic predator-prey link regulating the bacterivores in the marine environment. Mar. Ecol. Prog. Ser. 50: $137-145$

Wright, R.T., Coffin, R.B. (1984). Measuring microzooplankton grazing on planktonic marine bacteria by its impact on bacterial production. Microb. Ecol. 10: 137-149

Manuscript first received: June 25, 1992

Revised version accepted: October 9, 1992 